\title{
MEMPERSIAPKAN KEPEMIMPINAN DEMOKRATIS MASA DEPAN MELALUI PROGRAM PENGEMBANGAN KEMAMPUAN PERSPECTIVE TAKING DI SEKOLAH
}

\author{
Nanik Yuliati \\ Fakultas Keguruan dan Ilmu Pendidikan Universitas Jember \\ e-mail:nanikyuliati@gmail.com
}

\begin{abstract}
This paper presents a conceptual idea on using psychological approaches, more specifically the use of cognitive and developmental psychology paradigm to addressing leadership crisis that is currently concerned Indonesia. Many of the discussions and posts uploaded on the websites expressed a need for leaders who are more in line with the spirit of reform, namely a credible democratic leader, who sided with the people, egalitarian, and not in ways that authoritarian decision making and policy public. Judging from the paradigm of cognitive psychology, particularly social cognition, the ability to take the perspective of others (perspective taking) plays an important role in influencing the effectiveness of democratic leadership. Therefore, one way to obtain a democratic leader in the future is to develop the ability to take another person's perspective on the younger generation. In this case the educational institution (high school and university) is considered to be the most appropriate environment to host them. From a developmental perspective, perspective taking is a skill that can be developed because it is not an innate ability.
\end{abstract}

Keywords: Democratic leader, perspective taking, school

\begin{abstract}
Abstrak: Tulisan ini menyajikan suatu gagasan konseptual tentang penggunaan pendekatan psikologis, lebih khusus penggunaan paradigma psikologi kognitif dan perkembangan untuk menangani permasalahan krisis kepemimpinan yang saat ini dirasakan oleh bangsa Indonesia. Banyak kegiatan diskusi dan tulisan yang diunggah di website yang menyatakan adanya kebutuhan untuk memperoleh pemimpin yang lebih sesuai dengan spirit reformasi, yakni pemimpin yang demokratis yang kredibel, yang berpihak pada rakyat, egaliter, dan tidak menggunakan cara-cara yang otoriter dalam membuat keputusan dan kebijakan publik. Dilihat dari paradigma psikologi kognitif, khususnya kognisi sosial, kemampuan mengambil perspektif orang lain memainkan peran penting dalam mempengaruhi keektifan kepemimpinan demokratis. Oleh karena itu salah satu cara untuk memperoleh pemimpin demokratis di masa depan adalah dengan mengembangkan kemampaun mengambil perspektif orang lain pada generasi muda. Dalam hal ini lembaga pendidikan (sekolah menengah dan universitas) dipandang menjadi lingkungan paling tepat untuk menyelenggarakannya. Dari perspektif perkembangan, kemampuan ini dapat dikembangkan karena bukan merupakan kemampuan bawaan.
\end{abstract}

Kata kunci : Pemimpin demokratis, perspective taking, sekolah

Banyak pihak yang menyatakan bahwa saat ini bangsa Indonesia sedang mengalami krisis kepemimpinan. Suara atau pernyataanpernyataan tentang krisis kepemimpinan tersebut dapat kita simak dalam berbagai tulisan yang diunggah internet atau website. Berikut adalah beberapa contoh tentang pernyataan krisis kepemimpinan di Indonesia. Institut Kepemimpinan dan Sistem Politik Indonesia (2012) melakukan rangkaian kegiatan diskusi publik tentang krisis kepemimpinan di berbagai tempat, dan yang terakhir dilaksanakan di Grand Ballroom The Sultan Hotel, Jakarta, pada tanggal 19 Desember 2012 dengan mengambil tema "Mencari Solusi Krisis Kepemimpinan Politik Indonesia". Rangkaian diskusi publik ini jelas mengindikasikan adanya krisis kepemimpinan dan sebagai upaya menangani krisis tersebut. Lebih baru lagi, Lorca (2013) 
mengemukakan hasil riset terbaru yang menemukan bahwa tingkat kepercayaan masyarakat Indonesia terhadap kinerja kepemimpinan pemerintah masih rendah walaupun ada peningkatannya. Riset ini terungkap dari penemuan di lapangan oleh Edelman Indonesia dengan tajuk Edelman Trust Barometer 2013.

Krisis kepemimpinan juga dikemukakan jauh sebelumnya oleh Wibawa (2010) melalui makalahnya yang disampaikan dalam kegiatan latihan kepemimpinan mahasiswa Universitas Negeri Yogyakarta. Dalam makalahnya tersebut Wibowo menyatakan bahwa Indonesia mengalami krisis multidimensi sejak krisis moneter tahun 1997 namun krisis kepemimpinan merupakan krisis yang paling nyata. Menurutnya, saat ini bangsa Indonesia mengidamkan figur kepemimpinan yang dapat diandalkan dalam membuat perubahan-perubahan yang konstruktif untuk memajukan bangsa. Sedangkan Syarif (2005) menyatakan bahwa bangsa Indonesia saat ini telah berada pada era reformasi yang salah satu tujuan reformasi adalah membangun bangsa dan memperoleh pemimpin yang demokratis. Namun faktanya, saat ini para pemimpin bangsa belum cukup menampilkan kepemimpinan yang demokratis dan egaliter, bahkan nyaris kurang memiliki integritas intelektual dan etik moral yang dapat di pertanggung jawabkan di depan publik. Irawati (2004) dalam tulisannya tentang kepemimpinan efektif juga mengemukakan bahwa belakangan ini banyak kalangan yang membicarakan krisis kepemimpinan. Krisis ini muncul karena para pemimpin kurang memperhatikan kepentingan orang banyak dan kepentingan lingkungan.

Jika disimak, krisis kepemimpinan bangsa Indonesia pada dasarnya berkaitan dengan ketidakpuasan dari pihak rakyat terhadap kinerja kepemimpinan para pemimpin. Sesuai dengan spirit reformasi an sistem pemerintahan yang dianut, bangsa Indonesia menghendaki pemimpin yang lebih pro rakyat, egaliter, dan terbuka, yakni pemimpin yang demokratis. Demokrasi menunjuk pada suatu idealisme yang menyatakan bahwa semua manusia memiliki nilai yang sama, martabat yang sama, rasa hormat yang sama, dan harus diberi kesempatan yang sama untuk berpartisipasi sepenuhnya dalam menghayati dan mengarahkan kehidupan bermasyarakat, termasuk memperoleh akses yang sama kekuasaan politik, ekonomi, dan sosial budaya (Calderon, 2011). Namun faktanya, meskipun reformasi telah berlangsung lebih dari satu dasa warsa, sampai saat ini banyak pemimpin yang tak bisa memenuhi harapan itu. Banyak pemimpin yang lebih suka menampilkan sikap status quo, masih menampilan gaya era orde baru yang otoriter, angkuh, arogan, bahkan tidak jarang mereka cenderung kekanak-kanakan (impulsif dan egosentris) dalam membuat maupun melaksanakan sebuah kebijakan publik. Bahkan pemimpin umumnya pantang untuk turun dari kekuasaannya ketika rakyat menuntutnya karena rakyat menilai ia telah gagal, meskipun mereka itu menjadi pemimpin karena dipilih oleh rakyat melalui proses politik yang di dalamnya mengandung kontrak sosial.

Beberapa contoh gaya kepemimpinan yang masih cenderung status quo dan jauh dari spirit demokrtis misalnya dapat disimak dari kebijakan menaikkan harga BBM (Bahan Bakar Minyak) dan mobil murah baru-baru ini. Banyak komponen bangsa di seluruh wilayah yang mengatasnamakan rakyat yang menolak keinginan pemerintah untuk menaikkan harga BBM, namun pemerintah tetap bersikukuh bahkan dengan melakukan pengawalan dan pengawasan yang ketat dengan menggunakan kekuatan tentara dan polisi. Kenyataannya, apa yang terjadi saat ini tak lebih baik dari sebelumnya dan meleset 
dari prediksi yang dibuat oleh pemerintah. Malahan, faktanya mengarah pada apa yang telah diprediksikan oleh rakyat. Banyak rakyat kecil yang hidupnya semakin menderita setelah kenaikan BBM dan BLSM (Bantuan Langsung Sementara) tak memberi makna yang berari pada mereka. Banyak rakyat miskin yang hidupnya menjadi semakin sulit dengan kenaikkan harga BBM yang diikuti melonajaknya harga kebutuhan pokok. Banyak nelayan yang tidak melaut karena tak mampu membeli solar, dan konsumsi BBM tidak mengalami penurunan. Demikian pula nilai rupiah terhadap dolar malah semakin merosot. Sekarang ini, himpitan ekonomi kian mencekik kehidupan rakyat banyak dan para pemimpin tampak lepas tanggung jawab.

Terakhir, kebijakan mobil murah saat ini juga terkesan dipaksakan. Sepertinya pihak kementerian yang berwenang dalam membuat regulasi mobil murah ini cenderung lebih berpihak pada pengusaha daripada pada pihak-pihak yang melihat dampak negatif dari pemberlakuan kebijakan ini, seperti semakin meningkatnya kemacetan lalu lintas di jalan dan meningkatnya konsumsi BBM. Melalui pernyataan-pernyataan yang dikeluarkannya di media massa, para pemimpin yang terkait dengan kebijakan itu cenderung ingin memaksakan dapatnya kebijakan tersebut dilaksanakan. Pernyataan-pernyataan seperti "Awas ya jika nanti kamu membeli mobil murah.." atau "jangan hambat orang membeli mobil" atau dengan membuat rasioonalisasi tentang jumlah mobil dan penduduk di Indonesia yang lebih kecil dibanding rasio yang teramati di Thailand (namun tidak menyoroti kondisi sebaran penduduk di Indonesia dan kondisi jalanan yang sudah penuh sesak karena volumenya yang tak sebanding dengan volume kendaraan), mengesankan perilaku yang kekanakkanakan. Pernyaataan dan/atau argumentasi yang dikeluarkannya tidak berfokus pada masalah (problem oriented), tetapi lebih pada upaya untuk memaksakan kebijakannya diterima dan tercapainya tujuan sepihak.

Perilaku kekanak-kanakan juga sering ditampilkan oleh para anggota DPR (Dewan Perwakilan Rakyat) baik di pusat maupun di daerah. Dalam berbagai acara sidang mereka seringkali teriak-teriak dan terlibat dalam saling adu pukul ketika terjadi perbedaan pendapat atau pandangan, bahkan meskipun mereka tahu peristiwa itu disiarkan langsung oleh media telivisi. Mengesankan sekali jika mereka selalu ingin pendapat atau pandangannya diterima oleh pihak lain dan tak bisa menerima adanya keragaman. Tampak skali merek tak memiliki kemampuan psikologis untuk menangani konflik (keragaman) secara efektif.

Bagaimana menangani krisis kepemimpinan? Dalam bahasa psikologi, kata krisis bisa menunjuk pada dua konotasi, positif dan negatif. Konotasi negatif menyatakan bahwa krisis berhubungan dengan keadaan gawat atau genting, yang artinya saat ini Indonesia tak memiliki pemimpin yang benar-benar dapat menjalankan tugasnya sebagai pemimpin dan mengecewakan rakyat. Sepintas ini mungkin memang benar jika kita mengamati fakta bahwa banyak pemimpin bangsa ini yang umumnya yang lebih menekankan pada peran penguasa (senang memaksanakan kehendak/kebijakan) dan tidak bertindak sebagai pemimpin yang melayani kepentingan orang yang dipimpin/rakyat (servant leader). Konotasi positif menyatakan bahwa krisis bukan merupakan suatu kondisi patologis, melainkan suatu keadaan pencarian atau eksplorasi. Jadi, saat ini bangsa Indonesia sedang berusaha mencari (untuk menemukan) sosok pemimpin yang benar-benar bisa memimpin, dalam arti mampu melindungi rakyat dan membawa perubahan-perubahan yang lebih baik. Bila dicermati, kedua konotasi krisis tersebut sebenarnya mengarah 
pada keadaan yang sama, yakni "Indonesia saat ini membutuhkan pemimpin sejati, pemimpin yang benar-benar bisa memimpin." Seperti apakah pemimpin yang diinginkan oleh bangsa Indonesia? Sesuai dengan era yang sekarang ini diinginkan, era reformasi yang menghendaki kehidupan demokratis, maka pemimpin yang diinginkan adalah pemimpin yang demokratis, pemimpin yang egaliter, mengayomi, mendengarkan, dan berpihak pada rakyat, dan yang selalu membuat kebijakan yang populis.

Sulitnya menemukan figur kepemimpinan efektif pada saat ini mengindikasikan adanya kebutuhan untuk menyiapkan atau mendidik calon-calon pemimpin masa depan. Dalam konteks ini lembaga pendidikan dipandang sebagai institusi yang paling baik untuk mempersiapkan dan mendidik caloncalon pemimpin masa depan. Pemimpin yang berhasil adalah pemimpin yang mampu menangani keragaman secara efektif. Di sekolah setiap siswa berinteraksi dengan sejumlah siswa lain yang unik dan berbeda dengan dirinya. Demikian pula, lembaga pendidikan merupakan tempat yang paling baik untuk menyelenggarakan pembelajaran pengetahuan, keterampilan, dan sikap. Lembaga pendidikan seharusnya tidak hanya bertujuan membangun pengetahuan, keterampilan, dan sikap yang bersifat akademik belaka, tetapi juga bertanggung jawab untuk mempersiapkan pemimpin masa depan dengan cara yang terprogram secara terstruktur. Meskipun banyak orang - dengan berbagai macam alasan - ingin menjadi pemimpin, menjadi pemimpin yang efektif tidaklah mudah. Untuk menjadi seorang pemimpin yang efektif seseorang perlu memiliki karakteristik kepribadian tertentu misalnya memiliki bakat memimpin atau jujur dan bertanggung jawab - juga terdapat sejumlah kompetensi sosial yang bisa dipelajari atau dibelajarkan. Sebagian kecakapan memimpin mungkin merupakan sifat bawaan, dan sebagian yang lain merupakan hasil belajar. Secara keseluruhan, kemampuan menjadi pemimpin efektif merupakan fungsi dari kecakapan bawaan dan hasil belajar. Pembelajaran juga perlu dilakukan bukan hanya untuk membantu seseorang mempelajari keterampilan kepemimpinan, tetapi juga mengeksplorasi, mengasah, dan mengembangan bakat kepemimpinannya. Jadi pembelajarn merupakan kegiatan yang penting dalam proses mempesiapkan pemimpin masa depan.

Dari kajian psikologi, untuk menjadi pemimpin yang demokratis, individu perlu cakap dalam memahami mengambil perspektif orang lain (perspective taking). Kemampuan mengambil perspektif orang lain - untuk bahasan selanjutnya disingkat KMP merupakan salah satu komponen dalam kompetensi sosial yang dapat memainkan peran dalam mempengaruhi kepemimpinan efektif. Atas dasar pemikiran ini maka tulisan ini hendak mengetengahkan suatu gagasan konseptual tentang penerapan program pelatihan KMP bagi para siswa di sekolah sebagai upaya mempersiapkan kepemimpinan demokratis masa depan.

\section{PEMBAHASAN}

\section{Karakteristik Kepemimpinan Efektif dan Demokratis}

Kepemimpinan (leadership) berkenaan dengan penggambaran bagaimana seseorang melaksanakan tugas atau fungsinya sebagai seorang pemimpin. Dalam pengertian sederhana, kepemimpinan berkenaan dengan kemampuan me "manage" atau kecakapan managerial terhadap sekelompok orang yang telah bersepakat untuk mengikatkan diri ke dalam suatu organisasi guna mencapai tujuan bersama. Karena berkenaan dengan pelaksanaan tugas (mengelola atau mengorganisasikan) maka kepemimpinan 
bisa berhasil (efektif) atau tidak berhasil (tidak efektif) dalam mencapai tujuan bersama dari kelompok orang, organisasi, lembaga yang dipimpin.

Seorang pakar dalam kepemimpinan, Ricketts (2009) menyatakan bahwa kepemimpinan yang efektif dapat diukur melalui berbagai macam cara yang semuanya dapat dikelompokkan ke dalam tiga indikator berikut: (1) kelompok yang dipimpin memperlihatkan kinerja yang tinggi (performs well), (2) para pengikutnya mengalami kepuasan, dan (3) terjadi perubahan-perubahan yang signifikan mengikuti implementasi kepemimpinannya. Ricket juga mengatakan bahwa tak ada cara yang paling baik untuk menetapkan keefektifan kepemimpinan karena keefektifan itu tergantung pada sejumlah faktor, seperti situasi, budaya organisasi, dan bahkan visi dan misi atau tujuan organisasi. Demikian pula, keefektifan kepemimpinan juga dapat ditimbang menurut keterampilan yang dikuasai oleh pemimpian dalam bidang khusus yang berkaitan dengan kepemimpinannya. Dalam hal ini Ricket (2009) mengemukakan delapan keterampilan yang sering digunakan untuk menetapkan keefektifan kepemimpinan, yakni: EQ, kejelasan arah (tujuan), manajerial, komunikasi resiprokal, berpikir kontekstual, asimilasi kreatif, memberdayakan staf, dan ketekunan. Penggunaan kompetensikompetensi tersebut secara tepat akan memungkinkan pemimpin untuk berhasil dalam melaksanakan tugas kepemimpinannya (efektif). Jika seorang pemimpin dapat memberdayakan orang secara efisien, dapat berkomunikasi dengan anggota organisasi dan masyarakat dengan menggunakan $E Q$, atau memberikan arahan yang jelas tentang visi dan misi, maka konstituennya akan lebih mungkin untuk termotivasi secara instriknsik untuk memperlihatkan unjuk kerja yang tinggi dan membangun komitmen yang tinggi terhadap kelompok atau organisasinya.

Sebuah laporan penelitian tentang kepemimpinan abad 21 oleh Perrin dkk. (2010) menyampaikan sepuluh karakteristik kepemimpinan efektif dalam bisnis multilevel dalam organisasi di berbagai negara. Salah satu karakteristiknya menyatakan bahwa pemimpin yang berhasil pada abad ke21-baik secara individual maupun organisasional - adalah pemimpin yang mampu secara aktif menjaga kesadarannya tentang lingkungan dan menerapkan tindakan-tidakan yang relevan dengan tuntutan lingkungan.

Gitsham dkk. (tanpa tahun) mengemukakan tiga kluster pengetahuan dan kepimimpinan efektif, yakni: konteks, kompleksitas, dan keterikatan (context, complexity, connectedness). Konteks berkaitan dengan pemahaman resiko kebijakan dan peluang dari kondisi sosial, politik, dan tren lingkungan dalam mendukung kebijakan yang dibuat. Kompleksitas berkenaan dengan kemampuan untuk memimpin dalam menghadapi kompleksitas dan ambiguitas masyarakat yang dipimpin. Kluster terakhir, keterikatan, berkenaan dengan kemampuan untuk memahami pelaku dalam lanskap (pemandangan) politik an untuk bertindak dan membangun hubungan yang efektif dengan berbagai macam mitra kerja eksternal. Ketiga kluster kepemimpinan tersebut menggarisbawahi kebutuhan akan perlunya pemimpin memiliki pengetahuan, keterampilan, dan dapat bertindak secara efektif, khususnya dalam membangun kolaborasi dengan staf atau pihak lain. Satu elemen kunci bagi keberhasilan kepemimpinan dalam membangun dialog dan kerjasama/kolaborasi adalah kesadaran akan diri dan kesadaran tentang cara orang lain mempersepsi sesuatu dan cara kita berkomunikasi dengan mereka. Kompleksitas berkaitan dengan keragaman manusia yang perlu dipahami sebagai 
landasan untuk membuat keputusan yang memandang kompleksitas atau keragaman itu. Jika pemimpin dapat bertindak seperti ini, maka ia akan mampu untuk mengajak semua anggota organisasi untuk bekerjasama.

Berdasarkan definisi kepemimpinan dari beberapa ahli yang dikemukakan oleh Garry Yukl (dalam Wibawa, 2010), disimpulkan bahwa kepemimpinan yang efektif adalah kepemimpinan yang berhasil dalam: (1) memimpin aktivitas-aktivitas suatu kelompok untuk mencapai tujuan bersama; (2) melakukan proses komunikasi antar pribadi untuk mencapai beberapa tujuan tertentu; (3) membangun dan memelihara struktur dalam harapan dan interaksi; (4) mempengaruhi aktivitas sebuah kelompok yang diorganisasi ke arah pencapaian tujuan; (5) mengarahkan usaha kolektif untuk mencapai tujuan; (6) secara konsisten memberi kontribusi yang efektif terhadap orde sosial dan yang diharapkan; dan (7) menstruktur aktivitas-aktivitas serta hubungan-hubungan di dalam sebuah kelompok atau organisasi.

Dari sejumlah pengertian kepemimpinan efektif tersebut, jika dirangkumkan, aspek kunci untuk dapat melaksanakan kepemimpinan yang efektif adalah komunikasi. Komunikasi ini digunakan untuk berinteraksi dan membangun ketreikatan dengan dan mempersuasi orang yang dipimpin serta mengorganisasikan kegiatankegiatan organisasi untuk mencapai tujuan bersama. Tegasnya, komunikasi - lebih khusus komunikasi interpersonal memainkan peran penting untuk keberhasilan kepemimpinan.

Cara bagaimana pemimpin berkomunikasi dengan orang yang dipimpin atau dengan pihak luar dipengaruhi oleh model kepemimpinan yang dianutnya. Dalam lietartur kita bisa menemukan sejumlah nama gaya kepemiminan yang sedikit bervariasi antara penulis satu dengan lainnya atau menurut teori yang digunakan untuk mengklasifikasikannya. Karena keterbatasan ruang maka pada bagan ini tidak akan dikemukakan berbagai gaya kepemimpnan tersebut. Dalam konteks ini hanya akan diambil satu contoh klasifikasi gaya kepemimpinan dari Tannenbaun \& Schmidt (dalam Hersey \& Blanchard, 1992) yang dipandang mewakili. Tannenbaun dan Schmidt mengemukakan bahwa gaya kepemimpinan seseorang dapat digambarkan dalam suatu kontinum gaya komunikasi, yang merentang dari gaya otokratis (satu ujung kontinum) menuju gaya demokratis (ujung kontinum lainnya). Gaya otokratis tampak dari perilaku kepemimpinan yang dominan, berkuasa, dan otoriter dalam membuat keputusan maupun dalam melaksanakannya. Pemimpin seperti ini senang memberikan sanksi hukuman atau ancaman terhadap orang-orang dipimpinnya. Gaya kepemimpinan ini lebih berorientasi pada pelaksanakan tugas dan bukan orang. Sisi positif dari gaya ini adalah pengambilan keputusan yang cepat dan penggunaan struktur yang tegas.

Dalam gaya demokratis, pemimpin memperoleh kewenangan kekuasaan dari orang yang dipimpinnya. Jadi kekuasaan itu sebenarnya berupa mandat yang harus dilaksanakan sesuai dengan aspirasi orang yang dipimpin. Pemimpin demokratis lebih berorientasi pada orang dan bukan tugas. Mereka lebih mengutamakan kerjasama untuk mencapai tujuan, terbuka terhadap kritik dan senang menerima saran dari berbagai pihak termasuk dari bawahannya. Pemimpin demokratis senang mengajak diskusi dengan bawahan untuk mengkritisi gagasannya. Dalam mempersuasi orang lain (bawahan atau rakyat), pemimpin tidak menggunakan pendekatan kekuasaan dan menerapkan cara-cara otoriter. Pemimpin demokratis lebi senang untuk mengajak publik secara bersama-sama untuk 
menetapkan arah dan tujuan organisasi serta kegiatan-kegiatan yang perlu dilakukan. Pemimpin dengan gaya demokratis inilah yang sepertinya diharapkan oleh bangsa Indonesia saat ini.

Pendekatan lain tentang kepemimpinan yang dianggap baru dan yang mengarah pada spirit kepemimpinan demokratis adalah kepemimpinan pembantu (servantleadership), tetapi pendekatan ini lebih merupakan filosofi dari pada sebuah teori yang dapat dibuktikan. Servant-leadership lebih memusatkan perhatian pada mengembangkan pelayanan pada orang lain dari pada diri sendiri. Menurut Greenleaf (dalam Kinicki \& Kreitner, 2003), pemimpinpemimpin besar bertindak sebagai pembantupembantu, meletakkan kebutuhan-kebutuhan orang lain, termasuk karyawan, konsumen dan masyarakat sebagai prioritas pertama mereka. Servant-leadership ini ditandai oleh antara lain adanya kemauan mendengarkan, berempati konseptualisasi, persuasi, kesadaran, komitmen untuk mengembangkan dan membangun masyarakat.

\section{KMP sebagai Kompetensi Sosial yang Dapat Menyokong Kepemimpinan Demokratis}

Dari paparan tentang kepemimpinan efektif dan demokratis dapat ditarik simpulan bahwa kemampuan komunikasi - lebih khusus kemampuan komunikasi antar pribadi - merupakan aspek penting yang mempengaruhi keberhasilan dalam kepemimpinan. Kemampuan komunikasi merupakan salah satu kompetensi sosial yang perlu dikuasai oleh setiap orang guna membantunya mencapai tujuan dalam setiap urusan yang melibatkan hubungan atau interaksi dengan orang lain.

Kemampuan komunikasi dipengaruhi oleh sejumlah faktor, salah satunya kemampuan kognitif. Dalam komunikasi, kemampuan kognitif diperlukan untuk memahami perasaan, pikiran, dan tindakan orang lain. Oleh karena itu perbedaan dalam kemampuan kognitif akan mempengaruhi perbedaan dalam membaca dan memahami orang lain. Kemampuan memahami orang lain merupakan aspek krusial dalam komunikasi, sebab komunikasi merupakan suatu proses penyampaian pesan untuk mencapai tujuan tertentu, dan proses komunikasi akan berjalan efektif jika orang yang berkomunikasi itu saling bisa memahami satu sama lain.

Dari sudut padang kognisi sosial, untuk bisa memahami orang lain dengan mudah, kita harus mampu menyelami dan menghargai cara orang lain memandang, menilai, atau mempersepsi sesuatu sesuai dengan kerangka acuan internal mereka. Kemampuan seperti ini dalam literatur psikologi disebut kemampuan mengambil perspektif orang lain (perspective taking skills/ability). Pada bagian awal telah dikemukakan bahwa dalam tulisan ini digunakan singkatan KMP untuk menyebut kemampuan mengambil perspektif orang lain.

KMP merupakan suatu bentuk kemampuan kognitif. Konstruk ini berkembang dari psikologi kognitif, khususnya dari teori perkembangan kognitif Piaget dan teori perkembangan moral Kohlberg dan psikologi perkembangan. Seperti dikemukakan oleh Moates dkk. (2007), KMP sebegai suatu aktivitas mental (kognitif) dalam mempersepsi suatu situasi dari sudut pandang atau perspektif orang lain. Dengan kata lain, KMP menggambarkan keadaan mental ketika seseorang menampatkan dirinya dalam pikiran orang lain. Caruso dkk. (2006) dan Epley dkk. (2004) mendefinisikan KMP sebagai suatu kemampuan untuk memahami dan menerima perbedaan pendapat/pikiran, perasaan, dan tindakan orang lain dalam melihat, menginterpretasi, dan merespon situasi atau obyek yang sama dan bertindak secara efektif 
atas dasar pengakuan itu. Banyak ahli lain juga telah memberikan batasan tentang konstruk ini. Namun, jika dirangkumkan, semua definisi menunjuk pada elemen yang sama, yakni kemampuan untuk mengintegrasikan perspektif diri sendiri dengan perspektif orang lain sehingga menjadi perspektif bersama yang memungkinkan dua pihak dapat berkolaborasi secara efektif dalam rangka mencapai kebersamaan tanpa harus kehilangan otonomi pribadi. Beberapa penulis menyebut kemampuan ini sebagai komponen kognitif dari empati. Seperti dikemukakan oleh Steen \& Veen (2004), konsep empati memiliki dua dimensi, yakni empati (dimensi afektif) dan PT (dimensi kognitif).

Memperhatikan kandungan aspek psikologis yang ada di dalam KMP tersebut, tak dapat disangkal jika KMP akan memberikan dampak positif pada hubungan interpersonal atau interaksi sosial dan dengan demikian membawa dampak positif pada hubungan dan iklim organisasi. Seperti dikemukakan oleh Parker \& Axtell (2001), KMP merupakan suatu bangunan yang mendasar dalam interaksi sosial. Pemimpin yang dapat menampilkan KMP tinggi dalam berhubungan dengan anggota organisasi maupun pihak luar tentu akan lebih memiliki peluang untuk berhasil dibandingkan dengan pemimpin lain dengan KMP rendah.

Banyak hasil penelitian telah membuktikan pengaruh positif KMP pada hubungan sosial-interpersonal. Sebagai contoh, beberapa hasil penelitian eksperimental telah membuktikan keefektifan KMP dalam meningkatkan perilaku altruis (Maner dkk., 2002), keterampilan sosial (Dawson \& Fernald , 1987), kemampuan dalam bernegosiasi (Trotschell dkk., 2011), kepedulian terhadap lingkungan (Schultz, 2000), perilaku organisasional positif (Parker, Atkins, \& Axtell, 2008), kepemimpinan yang efektif (Steen \& Veen, 2005), keterikatan dan koordinasi sosial (Galinsky, Ku, \& Wang, 2005). KMP juga dapat membangun masyarakat demokratis (Calderon, 2011), menurunkan perilaku sosial negatif seperti stereotipe negatif(Weyant, 2007; Galinsky \& Moskowitz, 2000), dan menurunkan egosentrisme (Caruso, Epley, \& Bazeman, 2006).

Parker \& Axtell (2001) memperluas literatur KMP dengan mengkaji hubungan antara KMP dengan interaksi horisontal antara anggota organisasi (rekan kerja). Mereka menguji hipotesis yang diajukannya yang menyatakan bahwa KMP individu berhubungan secara positif dengan interaksi mereka. Hasil pengujian hipotesis memperlihatkan adanya korelasi positif antara KMP dengan kinerja kontekstual. Secara khusus, Parker and Axtell (2001) menemukan bahwa KMP pekerja akan memungkinkan individu lebih berhasil dalam membangun interaksi degan rekan kerja. Mereka juga menemukan bukti bahwa interaksi rekan sejawat akan menciptakan peluang sosial untuk meningkatkan familiaritas dan hubungan positif dengan KMP.

Dari paparan yang telah dikemukakan dapat ditarik simpulan bahwa KMP merupakan faktor krusial yang mempengaruhi keefektifan kepemimpinan. KMP memungkinkan pemimpian dapat lebih efektif dalam berbagi atau berinteraksi dengan orang yang dipimpinnya. Realitas hidup telah mengajarkan kepada kita bahwa untuk bisa hidup ditengah masyarakat secara secara efektif, baik sebagai pemimpin maupun pengikut, menuntut setiap orang untuk memiliki kemampuan memahami perspektif orang lain. Bahkan teori bisnis saat ini juga menyatakan bahwa KMP merupakan satu keterampilan penting yang harus dimiliki oleh setiap pemimpin yang ingin berhasil (Goleman dkk., 2002). Khususnya ini benar 
jika dirujuk bahwa seorang pemimpin pada dasarnya adalah melayani (bukan memerintah) orang-orang yang dipimpinnya dan dapat berhubungan secara efektif dengan orang-orang yang dipimpinnya itu sesuai dengan konteks budaya yang berlaku.

Dari temuan-temuan tersebut tampak bahwa KMP di samping terbukti memberikan dampak positif pada perilaku sosial umum, juga pada peningkatan perilaku organisasi dan kepemimpinan. Meskipun kajian KMP dalam psikologi organisasi dapat dikatakan belum banyak, setidaknya hasil penelitian tersebut membuktikan bahwa untuk memfasilitasi pencapai tujuan organisasi, para pemimpin perlu menampilakn KMP tinggi. Dengan KMP tinggi, setiap pimpinan akan dapat berhubungan secara efektif dengan atasan, kolega, bawahan, dan pihak eksternal dan dengan cara demikian ia lebih dapat membawa organisasi mencaai tujuantujuannya. Peran postif KMP dalam mempengaruhi keberhasilan dalam kepemimpinan dapat dijelaskan melalui model beberapa model teoretik berikut.

Bartunek dkk. (1983) mengidentifikasi tiga aliran utama pendekatan teoretik yang berkaitan dengan konstruk KMP, yakni komplementaritas subjek, kompleksitas kognitif, dan perkembangan orang dewasa. Prinsip komplementaritas didasarkan pada perlunya perspektif yang beragam dalam memahami kompleksitas dunia/lingkungan. Komplementaritas, dalam artian yang simpel menunjuk pada konseptualisasi yang tepat tentang beberapa konsep atau situasi yang rumit yang seringkali menuntut lebih dari satu landasan teoretik atau kerangka kerja. Dalam studi organisasi, berbagai macam teori motivasi dapat menjadi salah satu contohnya. Pendekatan kompleksitas kognitif menekankan bahwa kompleksitas pandangan dunia tergantung pada kemampuan untuk memegang berbagai perspektif secara simultan. Kompleksitas kognitifberisikan dua dimensi: diferensiasi dan integrasi. Deferensiasi melibatkan kemampuan untuk mengakui adanya dimensi jamak dalam suatu kelompok stimuli, sedangkan integrasi melibatkan pemahaman tentang hubungan antara dimensi-dimensi (Bartunek dkk., 1983). Diferensiasi dan integrasi menyebabkan individu untuk memahami lingkungannya dalam cara yang lebih integral dan detil. Teori perkembangan orang dewasa seperti diajukan oleh Kohlberg (1969) memusatkan perhatian pada KMP yang semakin kompleks sebagai suatu komponen penting dalam perkembangan manusia menuju kematangan kognitif dan sosial.

Teori Kegan berakar pada teori perkembangan kogniti Piaget dan teori perkembangan moral Kohlberg, khususnya yang berkenaan dengan seberapa jauh individu mampu memisahkan diri mereka dari perspektifnya sendiri, dan mampu untuk melihat itu secara obyektif sebagai suatu potongan dari sejumlah informasi yang relevan dalam suatu konteks tertentu. KMP ini memungkinkan individu untuk menggabungkan pandangan orang lain ke dalam konseptualisasi mereka sendiri tentang realitas. Teori Kegan ini juga disebut dengan teori tahap, dan menjelaskan bahwa KMP akan menjadi semakin baik ketika mereka menjadi orang yang lebih matang. Menurut Moates dkk. (2007), hasil kerja Kegan sebenarnya tak berbeda dengan Piaget san Kohlberg. Ketiganya memiliki konseptualisasi yang sama tentang KMP, yakni memandang KMP sebagai kemampuan kognitif. Dengan mengkonseptualisasikan KMP seperti itu, maka kecenderungan individu untuk mengambil perpsektif orang lain dapat diterapkan untuk semua bentuk interaksi, seperti hanya konstruk kepribadian dapat diterapkan dalam berbagai konteks.

Model teoretik lain berasal dari teori pemahaman interpersonal dari Selman (1980). Selman (1980) mengintegrasikan 
teori perkembangan kognitif (dan moral) Piaget dan teori pekembangan moral Kohlberg ke dalam suatu model teori untuk menjelaskan perkembangan kemampuan KMP yang ia sebut sebagai teori pemahaman interpersonal (human understanding) yang juga populer dengan nama teori perspective taking (Roan dkk., 2009). Selman mendefinisikan pemahaman interpersonal sebagai suatu kemampuan untuk memahami situasi sosial dalam arti perspektif jamak dari individu-individu yang terlibat di dalam interaksi itu. Dengan kata lain, pemahaman interpersonal ditentukan oleh kompleksitas KMP.

Menurut Selman, KMP berkembang mengikuti perkembangan kognitif seperti digambarkan oleh Piaget. Dalam hal ini Selman (1980) menggambarkan empat tahapan perkembangan KMP, yakni: egosentris (tahap 0), perspektif pihak satu (tahap 1), perspektif pihak 2 (tahap 3), dan perspektif dua pihak (tahap 4). Ada satu kondisi yang menggambarkan KMP sosial, yakni setelah tahap 4. Tahap 0 menggambarkan KMP yang bersifat egosentris yang berlangsung antara usia 3-6 tahun. Pada tahap ini anak bisa memahami adanya perbedaan antara dirinya dan orang lain dalam melihat sesuatu, namun tak bisa menerima perbedaan itu dan hanya mengakui perspektifnya sendiri. Tahap 1 berlangsung antara usia 6-8 tahun. Pada tahap ini anak sudah bisa memahami adanya perbedaan pandangan yang disebabkan oleh karena orang memiliki pengetahuan atau informasi yang berbeda. Tahap 2 berlangsung antara usia 8-10 tahun. Pada tahap ini anak sudah mampu memasuki pikiran orang lain dan memandang perspektifnya dari perspektif orang lain. Pada usia 10-12 tahun anak memasuki tahap ke 3, Pada tahap ini anak mampu mengintegrasikan perspektif dirinya dengan perspektif orang lain dan membentuk perspektif bersama (perspektif kita) yang melebihi perspektif diri (perkembangan kemampuan PT ini dapat diperiksa pada Epley \& Caruso, 2009; Karcher, 2002; Roan dkk., 2009).

Karcher (2002), seorang profesor dalam bidang psikologi klinis yang secara khusus mengembangan model konseling berpasangan (pair-counseling) membuat suatu model penjelasan teoretik tentang implikasi teori pemahaman interpersonal Selman pada strategi negosiasi interpersonal (interpersonal negotiation strategy) - untuk bahasan selanjutya disingkat SNI. Menurut Karcher, KMP mendasari SNI dalam arti bahwa KMP akan mendorong pemahaman interpersonal dan pemahaman interpersonal ini menentukan kesadaran individu tentang dampak sosial dari perbuatannya. Kesadaran ini akan menjadi dasar bagi individu untuk menggunakan SNI. SNI tersebut berhubungan dengan dua orientasi interpesonal (OI): melayani (selftransforming. ST) dan mengambil (others transforming, OT). SNI ini ditentukan oleh empat tingkatan perkembangan KMP. Untuk lebih jelasnya bisa dilihat pada tabel 1 berikut:

Tabel 1. Model Teoretik Hubungan antara KMP, SNI, dan OI. Deskripsi perkembangan KMP dalam teori Selman dan implikasinya pada SNI

\begin{tabular}{|c|c|c|}
\hline \multirow{2}{*}{ KMP } & \multicolumn{2}{|c|}{ SNI } \\
\hline & ST & OT \\
\hline $\begin{array}{l}\text { Tahap 3: } \\
\text { KMP dua } \\
\text { pihak } \\
\text { (Kolaboratif) }\end{array}$ & \multicolumn{2}{|c|}{$\begin{array}{l}\text { Berbagi kebutuhan dan masalah } \\
\text { bersama. Semua tindakan } \\
\text { dipertimbangkan dampaknya pada } \\
\text { hubungan. Menekankan kebersamaan }\end{array}$} \\
\hline $\begin{array}{l}\text { Tahap 2: } \\
\text { KMP pihak } \\
\text { dua } \\
\text { (reciprokal) }\end{array}$ & $\begin{array}{l}\text { Bertanya, meminta } \\
\text { penjelasan, barter, } \\
\text { melayani }\end{array}$ & $\begin{array}{l}\text { Mempengaruhi, } \\
\text { membuat } \\
\text { argumentasi, } \\
\text { menjadi } \\
\text { pemenang }\end{array}$ \\
\hline $\begin{array}{l}\text { Tahap 1: } \\
\text { KMP pihak } \\
\text { satu } \\
\text { (Unilateral) }\end{array}$ & $\begin{array}{l}\text { Patuh, menyetujui, } \\
\text { mengalah }\end{array}$ & $\begin{array}{l}\text { Mendikte, } \\
\text { memerintah, }\end{array}$ \\
\hline $\begin{array}{l}\text { Tahap 0: } \\
\text { egosentris }\end{array}$ & $\begin{array}{l}\text { Menarik diri, } \\
\text { bersembunyi, lari, } \\
\text { merengek, merajuk }\end{array}$ & $\begin{array}{l}\text { Menantang } \\
\text { berkelahi, } \\
\text { memukul, }\end{array}$ \\
\hline
\end{tabular}


Individu pada KMP egosentris memperlihatkan pemahaman interpersonal yang tidak matang, mementingkan diri sendiri dan mengabaik kepentingan orang lain. KMP egosentris tampak impulsif, tampak tidak peduli dengan ramifikasi tindakan mereka. Namun, anak-anak lain yang telah mampu untuk mengkoordinasikan dua perspektif sosial secara simultan akan menyadari bahwa orang lain memiliki suatu kehidupan psikologis internal yang tak kasat mata dan tak dapat disimpulkan secara obyektif. Kesadaran ini akan mengarahkan mereka untuk melihat norma-norma sosial guna memprediksikan suatu tindakan tertentu dan dampak dari tindakan itu. Anak dengan KMP tahap 1 menggunakan strategi unilateral. Untuk melakukan negosiasi, mereka bisa menggunakan SNI dengan cara menuruti, memberi atau mengalah $(S T)$ atau menguasai, memerintah, menyakiti (OT). Anak dengan KMP tahap ke 2 akan menggunakan strategi resiprokal dalam bernegosiasi, yakni dengan cara meminta alasan, barter, atau mengikuti (ST) atau dengan cara sebaliknya, yakni membuat argumentasi, mempengaruhi, atau menjadi orang pertama $(O T)$. Anak dengan KMP tahap ketiga sudah mampu untuk bekerjasama dan menggunakan strategi kolaboratif, berbagi kepentingan, menempatkan kepentingan bersama di atas kepentingan individual, dan membangun perspektif bersama (we perspective). Semua tindakan yang akan diambil dipertimbangkan dampaknya pada hubungan, dan hanya tindakan yang menjaga kebersamaan yang akan dipilih untuk dilakukan.

\section{Analisis Program Pengembangan KMP di Sekolah}

Program pengembangan kemampuan KMP di sekolah sangat dimungkinkan karena dari kajian teori-teori yang memberikan penjelasan tentang kemampuan KMP, khususnya teori perkembangan kognitif Piaget dan teori pemahaman interpersonal atau teori perspective taking dari Selman, diperoleh pemahaman bahwa KMP bukan suatu kemampuan yang bersifat bawaan melainkan kemampuan yang berifat perkembangan (developmental). Kemampuan KMP berkembang sejalan dengan perkembangan kemampuan kognitif dan moral seperti digambarkan oleh Piaget dan Kohlberg. Seperti telah dikemukakan, Selman (1980) menegaskan bahwa KMP berkembang melalui empat tahapan dari usia 0 hingga usia 14 tahun, mulai dari tahap paling rendah (egosentris) hingga tahap palaing matang (sosial). Setiap tahapan tersebut berkembang mengikuti tahapan perkembangan kognitif.

Pelatihan dalam kemampuan KMP dimungkinkan bukan hanya karena KMP merupakan kemampuan yang dapat dipelajari/dikembangkan, tetapi juga karena beberapa anak dapat mengalami hambatan dalam mengembangkan kemampuan KMP karena beberapa hal. Banyak hasil penelitian menyatakan bahwa anak-anak yang memperolah pengasuhan kurang baik (mistreated) tidak mampu mengembangkan kemampuan KMP secepat anak lain. Burack dkk. (2006) menemukan bahwa anak belasan tahun (usia rata-rata 15 tahun) yang mengalami pengasuhan tidak baik memperlihatkan kemampuan KMP sepadan dengan kemampuan anak usia sepuluh tahun. Diduga ini disebabkan oleh karena anak-anak salah asuh tersebut hanya melakukan sedikit interaksi dengan orang tuanya atau karena mereka mengamati (belajar) perilaku sosial yang buruk pada orang tuanya. Epley \& Caruso (2009) mengemukakan tiga hambatan, yaitu: kegagalan mengaktifkan proses mental untuk secara aktif berpikir tentang keadaan mental orang lain, pemeliharaan kebiasaan egosentris, dan penyesuaian yang tidak akurat karena minimnya infomasi atau pengetahuan yang dimiliki. Sedangkan Epley dkk. (2004) 
mengemukakan bahwa hambatan dalam KMP bisa terjadi karena individu mungkin cenderung overestimate dalam menilai persepsi orang lain-guru sering overestimate dalam menilai kejelasan kuliahnya, orang tua overestimate dalam menilai kejelasan instruksinya pada anak, dan pasangan kekasih yang overestimate dalam menilai kejernihan emosinya. Jadi, upaya intervensi perlu memerhatikan pada faktor-faktor penghambat tersebut.

Secara histroris konstruk teoretik KMP dapat ditelusuri dalam kerja Jean Piaget dalam teori perkembangan kognitif dan Kohlberg dalam eori perkembangan moral. Teori Piaget menyajikan suatu perkembangan KMP yang paling awal. Piaget mengemukakan gagasan tentang KMP guna membuat penjelasan tentang satu aspek perkembangan anak, penalaran spasial. Dalam serangkaian studi yang dilakukannya, Piaget menemukan bahwa anak-anak dari usia yang berbeda (dan karenanya memiliki tingkat kemampuan kognitif yang berbeda pula) memandang lingkungannya dalam cara yang sangat berbeda. Dalam suatu eksperimennya - yang dikenal dengan "three mountain test,"-Piaget dan Inhelder (1968) menemukan bahwa dalam tahap perkembangannya yang lebih awal anak tidak mampu untuk mendeskripsikan secara akurat obyek yang diamatinya dari orentasi (pandangan) orang lain. Dengan kata lain, pemahaman terhadap lingkungan akan bekembang secara penuh pada periode dewasa dan perkembangan ini melibatkan perspektif yang bersifat relatif dan kemampuan kognitif yang belum berkembang baik pada usia anak. Ketika anak telah mencapai perkembangan orang dewasa maka kemampuan mereka dalam melihat dunia melalui mata orang lain (mengambil perspektif orang lain) menjadi lebih sempurna. Kemampuan ini menjadi bagian integral dari pemahaman interpersonal (interpersonal understanding). Jadi, KMP menjadi komponen esensial dalam upaya memahami orang lain.

Dalam teori perkembangan penalaran moral Kohlberg (1969) - disebut teori tahap anteseden lain dari teori perspektif taking modern dapat ditemukan. Kohlberg menyatakan bahwa ketika individu mengalami perkembangan kognitif, mereka juga mengalami perkembangan penalaran moral melalui enam tahapan. Perkembangan moral berkaitan dengan kemampuan membuat keputusan yang didasarkan pada prinsip benar dan salah dengan mempertimbangan minat (perspektif) orang lain. Dalam teori Kohlberg ini kita dapat melihat suatu penekanan pada perkembangan KMP sebagai suatu penanda atau ciri dari perkembangan sosial.

Dalam kaitannya dengan pengembangan generasi muda, lembaga pendidikan seharusnya tidak hanya bertujuan membangun pengetahuan dan keterampilan akademik, tetapi juga mempersiapkan peserta didik agar mampu menjadi insan-insan pembaharu dan pengubah dunia di kemudian hari nanti. Agar menjadi insan-insan pembaharu, maka pesera didik perlu belajar menjadi seorang pemimpin dan menguasai karakteristik kepemimpinan efektif. KMP merupakan kemampuan yang harus dikembangkan pada diri setiap siswa jika kita berharap untuk memperoleh pemimpin masa depan yang efektif guna menangani krisis kepemimpinan saat ini.

Lembaga pendidikan - khususnya di tingkat sekolah menengah dan perguruan tinggi- merupakan tempat yang paling tepat untuk mempersiapkan dan mendidik (mencetak) calon-calon pemimpin masa depan. Secara khusus, lembaga pendidikan merupakan tempat yang strategis untuk mengembangkan KMP pada siswa. Setidaknya ini berakar pada fakta bahwa lembaga pendidikan menjadi tempat 
berinteraksinya individu-individu dari berbagai latar belakang, tempat yang mengandung keragaman dan mengkondisikan siswa untuk belajar dan menangani keragaman itu. Pelatihan KMP di sekolah tidak hanya bermanfaat untuk mempersiapkan pemimpin masa depan, tetapi KMP juga dapat memberikan dampak pada prestasi akademik. Siswa dengan KMP tinggi lebih mungkin berhasil menangani kesulitan dengan teman dan guru dibandingkan dengan siswa lain dengan KMP rendah. Kondisi ini tentu saja memungkinkan siswa dengan KMP tinggi lebih mungkin dapat belajar tanpa hambatan dibandingkan siswa lain dengan KMP rendah.

Banyak penelitian telah membuktikan bahwa keragaman struktural yang terdapat di sekolah dan perguruan tinggi akan memberi siswa kesempatan untuk bertemu dan berinteraksi dengan orang lain dan pandangan yang berbeda dengan dirinya (Hurtado dkk., 1998). Meskipun demikian, fakta itu tidak akan menjamin bahwa siswa akan dapat bertinda secara efektif dalam menangani keragaman itu. Untuk dapat bertindak secara efektif dalam menangani keragaman, mereka perlu untuk dipersiapkan dan belajar dari perspektif yang berbeda dengan perspektif dirinya. Artinya, siswa harus secara intensional mengembangkan kemampuannya dalam mempelajari dan mengambil perspektif orang lain.

Di negara lain, misalnya Amerika, pelatihan KMP telah dipandang menjadi satu kebutuhan yang penting yang perlu diselenggarakan di sekolah dan perguruan tinggi. Sebagai contoh, suatu survey yang dilakukan oleh Reason (2011) untuk mengungkap sikap mahasiswa dan staf universitas terhadap perlunya pemberina program pengembangan KMP di perguruan tinggi dengan menggunakan 23000 mahasiswa dan 8000 profesional (staf pengajar, karyawan, dan pimpinann universiyas) menemukan bahwa 93\% mahasiswa dan $97 \%$ profesional sangat setuju bahwa KMP harus menjadi tujuan yang esensial di perguruan tinggi.

Cara atau strategi bagaimana KMP akan dikembangkan bisa menggunakan berbagai pendekatan interenvensi baik secara tunggal maupun kombinatif, bisa melalui format bimbingan klasikal, kelompok, konseling, atau pelatihan. Strategi mana yang akan dipilih tergantung pada sejumlah variabel. Namun, idealnya program ini dilaksanakan secara terstruktur. Jika dilaksanakan secara terstruktur, maka program perlu dilaksanakan secara reguler/terjadwal dan dengan aktivitasaktovitas yang telah dirancang dengan jelas di dalam kurikulum intervensi. Berbagai teknik yang telah terbukti efektif untuk mengembangkan pada kelompok populasi di negara lain KMP antara lain pemodelan, bermain peran, pair-counseling, dan CBT.

\section{SIMPULAN}

Banyak pernyataan bahwa saat ini bangsa Indonesia sedang mengalami krisis kepemimpinan. Krisis muncul dari tidak terpuaskannya kebutuhan untuk memperoleh pemimpin yang dapat memimpin bangsa dengan gaya yang sesuai dengan spirit reformasi, yakni demokrasi. Para pemimpin sekarang ini tampak masih memperlihatkan sikap status quo dalam membuat kebijakan publik, yakni mengunakan pendekatan kekuasaan dan cara-cara cenderung otoriter. Sulitnya menemukan sosok pemimpin yang diharapkan pada saat ini, maka perlu ada upaya untuk mempesiapkannya. Cara yang paling baik untuk mempersiapkan pemimpin masa depan yang diharapkan adalah melalui jalur pendidikan. Jadi lembaga pendidikan memainkan peran enting bukan hanya mencerdaskan bangsa tetapi juga dalam mencetak pemimpin-pemimpin efektif masa depan. Lembaga pendidikan bisa mendidik 
paa siswa untuk belajar atau mempelajari berbagai karekteristik kepemimpinan efektif yang diharapkan, yaitu kepemimpinan demokratis di sekolah. Lembaga pendidikan menjadi lingkungan yang sangat mungkin bagi setiap siswa untuk belajar kepemimpinan demokratis karena di sekolah setiap siswa bertemu dengan berbagai macam keragaman dan harus menangani keregaman itu secara efektif.

Dari sudut tinjuan psikologis, keefektifan kepemimpanan merupakan fungsi dari kemampuan bawaan dan hasil belajar. Lingkungan dapat merancang kondisi-kondisi untuk membantu siswa mengungkap, mengasah, dan mewujudkan potensi di samping menghambat potensi-potensi yang tak diharapkan dan membelajarkan pengetahuan, sikap, dan keterampilan yang mendukung kepemimpinan efektif (demokratis). Salah satu hal krusial yang mendukung keefektifan kepemimpinan demokratis adalah komunikasi. Keefektifan komunikasi itu sendiri dipengaruhi oleh sejumlah faktor. Ditilik dari paradigma kognitif, khususnya kognisi sosial, keberhasilan komunikasi dipengaruhi oleh kemampuan seseorang dalam memahami orang lain (kemampuan dalam membuat pemahaman interpersonal). Orang akan lebih mudah dalam memahami orang lain jika ia mampu memasuki dunia pikiran orang lain, dalam arti perspektif mereka dalam menilai sesuatu. Dengan kata lain, kemampuan komunikasi dipengaruhi oleh kemampuan untuk memahami orang lain, dan kemampuan untuk memahami orang lain dipengaruhi oleh kemampuan untuk mengambil perspektif orang lain.

Jadi, untuk mempersiapkan pemimpin masa depan yang demokratis lembaga pendidikan perlu membantu setiap siswa mengembangkan kemampuan untuk mengambil persektif orang lain. Banyak hasil penelitian telah membuktikan bahwa kemampuan mengambil perspektif orang lain dapat meningkatkan perilaku sosial positif dan menurunkan perilaku sosial negatif. Lebih khusus, kemampuan ini dapat mempengaruhi perilaku organisasi dan kepemimpinan. Cara bagaimana sekolah akan melaksanakan program ini bisa dipertimbangkan secara unik sesuai dengan kondisi sekolah, namun idealnya program ini dilaksanakan sebagai program yang bersifat reguler dan terjadwal dalam kurikulum pengembangan kepribadian siswa (bimbingan dan konseling sekolah).

\section{DAFTAR PUSTAKA}

Bartunek, J. M., Gordon, J. R., \& Weathersby, R. P. (1983) Developing "complicated understanding in administrators. Academy of Management Review, 8 (2), 273-284.

Burack, J.A., Flanagan, T., Peled, T., Sutton, M., Zygmuntowicz, C., \& Manly, J.T. (2006) Social Perspective-Taking Skills in Maltreated Children and Adolescents. Developmental Psychology, 42, 207-217.

Calderon, J. (2011). Perspective Taking as a Tool for Building Democratic Society. Diversity \& Democracy: Civic Learning for Shared
Futures, 14(1), 5-7.

Caruso, E, M., Epley, N., \& Bazerman, M. H. (2006). When perspective taking increases taking: Rective egoisme in social interaction. Journal of Personality and Social psychology, 91 (5), 872-889.

Dawson, G., \& Fernald M. (1987). Perspectivetaking ability and its relationship to the social behavior of autistic children. Journal of Autism and Developmental Disorders, $17(4), 487-498$

Epley, N., Morewedge, C.K., \& Keysar, B. (2004). 
Perspective taking in children and adults: Equivalent egocentrism but differential correction. Journal of Experimental Social Psychology, 40 (6), 760-768.

Epley, N., \& Caruso, E. M. (2009). Perspective taking: Misstepping into others' shoes. In K. D. Markman, W. M. P. Klein, \& J. A. Suhr (Eds.), Handbook of imagination and mental simulation (pp. 295-309). New York: Psychology Press.

Galinsky, A.D., Ku, G., \& Wang, C.S. (2005). Perspektive -Taking and Self-Other Overlap: Fostering Social Bonds and Facilitating Social Coordination. Group Pocess \& Intergroup Relations, 8 (2), 109124.

Galinsky, A.D., \& Moskowitz, G.B. (2000). Perspective Taking: Decreasing Stereotype Expression, Stereotype Accessibility, and In-Group Favoritsm. Journal of Personality and Social Psychology, 78 (4), 708-724.

Goleman, D., Boyatzis, R., \& McKee, A. (2002). Primal Leadership: Realizing the Power of Emotional Intelligence. Boston: Harvard Business School Press.

Hersey, P., \& Blanchard, K. (1992). Manajemen Perilaku Organisasi: Pendayagunaan Sumberdaya Manusia. (Edisi Keempat). Jakarta: Penerbit Erlangga.

Hurtado, S., Jeffrey F. M., Alma R. C., dan Walter, R. A. (1998). Enhancing Campus Climates for Racial/Ethnic Diversity: Educational Policy and Practice. The Review of Higher Education, 21 (3), 279-302.

Irawati, N. (2004). Kepemimpinan Efektif, Kepemimpinan yang Mampu Mengambil Keputusan Tepat. Diakses dari: http://repository.usu.ac.id/bitstream/12345 6789/1226/3/manajemen-nisrul.pdf.txt. pada 1 Desember 2012.

Karcher, M.J. (2002). The Principles and Practice of pair Counseling: A Dyadic Developmental Play Therapy for Aggressive, Withdrawn, and Socially Immature Youth. International Journal of
Play Therapy, 11 (2), 121-147.

Kinicki, A. \& Kreitner, R. (2003). Organizational Behavior: Key Concepts, Skills and Best Practices. New York: McGraw-Hill/Irwin

Kohlberg, L. (1969). Stage and Sequence: The cognitive-developmental approach to socialization. Dalam D.A. Goslin (Ed.). Handbook of socialization theory and research. (hlm. 347-480). San Diego, CA: Academic Press.

Lorca, R. I. (2013). Indonesia Krisis Kepemimpinan. Diakses dari: http://pedomannews.com/sosialbudaya/19394-indonesia-krisiskepemimpinan, pada 4 Februari 2013.

Maner, J.K., Luce, C.L., Neuberg, S.I., Cialdini, R.D., Brown, S., \& Sagarin, B.J. (2002). The Effect of Perspective Taking on Motivations for Helping: Still No Evidence for Altruism. Personality and Social Psychology Bulletin, 28(11), 1601-1610.

Moates, K. N., Harris, S. G., Feild, H.S. \& Armenakis, A. A. (2007). Perspective Taking And Leader-Member Exchange In Supervisor/Subordinate Dyads: A Hierarchical Linear Modeling Investigation. Academy of Management Proceedings, 34, 1-6. Diakses dari: http://proceedings.aom.org/content/2007/1 /1.188.full.pdf, pada 1 Januari 2013.

Parker, S. E., Atkins, P. W. B., \& Axtell, C. M. (2008). Building better work places through individual perspective taking: A fresh look at a fundamental human process In G. P. Hodgkinson \& J. K. Ford (Eds.), International Review of Industrial and Organizational Psychology, Vol. 23, pp. 149.

Perrin, C., Blauth, C., Apthorp, E., Daniels, S., Marone, M., Thompsen, J., dkk. (2010). Developing the 21st-Century Leader: A multi-level analysis of global trends in leadership challenges and practices. Diakses dari:., pada 12 Desember 2012.

Piaget, J., \& Inhelder, B. (1969). The Psychology 
Of The Child. London: Routledge And Kegan Paul.

Ricketts, K.G. (2009). Competent Leaders: What Effective Leaders Do Well. Elk1-101: Leadership Behavior. Issued 2. Diakses dari http://www.ca.uky.edu/agc/pubs/elk1/elk 1101/elk1101.pdf., pada 12 Desember 2012.

Reason, R.D. (2011). Encouraging Perspetive Taking among College Students. Journal of Diversity \& Democracy. Civic Learning for Shared Futures, 14 (1), 8-10.

Roan, L., Strong, B., Foss., P., Yager, M., Gehlbach, H., \& Metcalf, K. (2009). Social Perspective Taking. Arlington: United States Army Research Institute.

Selman, R. L. (1980). The growth of interpersonal understanding: Developmental and clinical analyses. New York: Academic Press.

Selman, R.L. (2003). The promotion of social awareness: Powerful lesson from the partnership of developmental theory and classroom practice. New York: Russel Sage Foundation.

Schultz P. W. (2000). Empathizing With Nature: The Effects of Perspective Taking on Concern for Environmental Issues. Journal of Social Issues, 56 (3), 391-406.

Steen, T. \& Veen S.V. (Tanpa Tahun). Teaching perspective Taking: Why It's Important How it Might be Done. Holland: Departement of Economics, Management, and Accounting, Hope College. Diakses dari: http: // ww w. c bfa.org/ Steen_VanderVeen.pdf., pada 12 Desember 2012.

Syarif, S. K. (2005). Reformulasi kepemimpinan nasional di tengah arus tuntutan demokratisasi masyarakat lokal. AlMawarid, 13, 44-53.

Trotchell, R., Loschelder, D.D., Huffmeier, J., \& Schwartz. K. (2011). Perspective taking as a means to overcome motivational barriers in negotiations: when putting oneself into the opponent's shoes helps to walk toward agreements. Journal of Personality and Social Pathology, 101 (4), 771-790.

Weyant, J. M. (2007). Perspective Taking as a Means of Reducing Negative Stereotyping of Individuals Who Spak English as a Second Language. Journal of Applied Social Psychology, 37 (4), 703-716.

Wibawa, S. (2010). Kepemimpinan. Makalah dipresentasikan dalam Kegiatan Latihan Kepemimpinan Mahasiswa Universitas Negeri Yogyakarta. Diakses dari: ., pada 12 Desember 2012.

Institut Kepemimpinan dan Sistem Politik Indonesia. (2012). Mencari Solusi Krisis Kepemimpinan Politik Indonesia. Diskusi Publik di Jakarta, 20 Desember 2012. Diakses dari: http://pemimpin idaman.com/diskusi-publik-di-jakartamencari-solusi-krisis-kepemimpinanpolitik-indonesia/., pada 1 Januari 2013. 